\title{
CONSUMER PREFERENCE IN TYPE OF HOUSE APPEARANCE OFFERED BY HOUSING DEVELOPER IN SEMARANG
}

\author{
Ali Alsharef Khlil Khalifah ${ }^{*}$, Edward E. Pandelaki, Siti Rukayah \\ Program Studi Magister Teknik Arsitektur, Fakultas Teknik, Universitas Diponegoro, \\ Jl. Hayam Wuruk 5, Kampus Undip Pleburan, Semarang, Indonesia
}

\begin{abstract}
Abstrak
Persaingan tajam antara bisnis properti perusahaan meningkat seiring dengan bertambahnya populasi dengan meningkatnya kebutuhan rumah. Tujuan dari penelitian ini adalah untuk menganalisis preferensi konsumen tentang penampilan rumah yang ditawarkan oleh pengembang perumahan di Semarang. Populasi dalam penelitian ini pengunjung dari pameran perumahan diselenggarakan di beberapa Mall di Semarang. Teknik analisis yang digunakan adalah persepsi responden tentang preferensi konsumen dalam jenis penampilan rumah dengan analisis deskriptif karena dalam analisis deskriptif akan mencerminkan pendapat sebenarnya dari responden penelitian. Berdasarkan hasil dan analisis, kesimpulan dalam penelitian ini adalah: Jenis rumah yang konsumen paling sukai adalah tipe minimalis dan yang kedua adalah tipe Vernakular. Hal ini karena bentuk Minimalist yang ramping dan menarik di hampir setiap ruang. Tipe Minimalis juga memiliki keunikan yang sangat sederhana dan menarik juga modern. Jenis minimalis sangat populer dan harga yang lebih rendah. Sementara itu, jenis vernakular lebih hampir oleh pengusaha yang berasal dari masyarakat kelas tinggi dan mereka mengatakan jenis vernakular besar dan mewah, juga georgeous.
\end{abstract}

Kata kunci : preferensi konsumen; penampilan rumah; pengembang rumah

\begin{abstract}
[Title: Consumer Preference in Type of House Appearance Offered by Housing Developer in Semarang] Competition among companies property enhances along with increasing population coupled with the increasing needs of house. The purpose of this study is to analyze the consumer preference in type of house appearance offered by housing developer in Semarang. The method used in this research is qualitative methods because the qualitative methods more better in explaining the phenomena in practices. The analytical method used is depending on respondent perception about consumer preference in type of house appearance with descriptive analysis. The house type that the consumer prefer mostly is minimalist type and the second is Vernacular type. This is because the spare and streamlined is charming in almost any space. Minimalist type house also have uniqueness that is very simple and attractive also modern. The minimalist type house is very popular and the price lower.
\end{abstract}

Keywords : consumer preference; house appearance; developer

\section{Background}

Current population growth, especially in the city of Semarang experience developed quite rapidly. From year to year in the city's population is increasing. The increase in population is caused by various factors, including the movement of people from various areas in Indonesia who came to the city of Semarang. The increase was also resulting in increased human needs, both primary and secondary needs. From the start of daily necessities to the tertiary needs, including the need for shelter. Therefore the larger the property business opportunities, as seen by

\footnotetext{
${ }^{*}$ Penulis Korespondensi.

E-mail: ali_alsharef80@yahoo.com
}

the increasing number of property companies (Ahsen and Gulcin, 2005).

Increasingly rapid population growth today must be able to go hand in hand with increased efforts of subsistence. Basic needs that must be met in addition to clothing and food is housing. Therefore, a growing number of housing demand, attract investors to build a new residential area that provide comfort, security and affordable prices. Competition among companies property sharper with increasing population coupled with the increasing needs of the home. It can provide jobs or new businesses that have good prospects. In this era, a company must be able to follow the changes that occur both inside and outside the company. Of course, to follow the various changes is not easy. Companies that tend to traditionally 


\section{Teknik, 36 (2), 2015, 92}

minded and do not expect any changes, will certainly encounter many difficulties encountered in its operations, especially in the effort to make consumers interested in buying products produced by the company (Johnson, 2006).

Each property company certainly has its advantages and disadvantages of each in terms of housing products they offer. The issue is whether the housing product is capable of making consumers finally interested in purchasing. If it turns out housing products issued by the company is not in accordance with what is desired by consumers, then it will lead to failure for the company. Various ways can be done in order to achieve success and the success of a company to attract customers. Usually the company emphasizes differentiation, such good quality products and services so as to distinguish them from competitors. The target company will be achieved by a company must be supported by whether or not the product. In addition to price, quality home, the appearance of a home is important to attract buyers. The better the quality and the shape of the house then the consumer will be more interested in buying the output offered by the company property.

Based on the background of the study above, so this research will analyze the consumer preference in type of house appearance offered by housing developer in Semarang.

\section{Basic Concepts}

\subsection{House and Housing}

House is a product of evolution of human civilization and a perfect reflection of the social system that created it. In short, the house was declared external geometry of three-dimensional structure, projected on a physical geographical space, internally organized and divided into differentiated but highly interrelated and communicate functional space (Ogunshakin, 1988). A house as described can also be seen as a place to stay for human habitation is a crude hut or house complex, and whatever degree of intrinsic architectural interest, a real house, providing shelter and act as a focal point for day to day living (Ahsen and Gulcin, 2005). The characteristics of house depends on the climate and terrain, building materials, technology skills and cultural determinants such as social status and economic resources.

House is more than just a shelter. It is a source of identity and status as well as demonstrators or both to the outside world. It may be identified with and place of assembly for the wider family or lineage that occupies from day to day. It can also be the location for businesses that provide the basic necessities of life, or that add primary income (Ahsen and Gulcin, 2005).

Housing is defined as the total housing environment or micro district including physical structure (Salau, 1992). This is seen as the physical environment in which the basic unit of the family and society should develop. Residential structure is the place in which people are placed for lodging, accommodation or even a working life.
According to Abram (1964), "housing is not only shelter, but also part of the structure of the life of the environment and social environment as a whole". It touches on many aspects of economic activity and development. So housing providing social contact, good image, a sense of belonging and social status indicators. Housing is the process of providing a large number of residential buildings permanently with adequate physical infrastructure and social services are planned, decent, safe and sanitary environment to meet basic needs and social population and are intended to provide safety, comfort and convenience for the user (Policies National Housing, 2004.

Aroni (1982) and Achuenu (2002), shows that housing should be home, resting place with the basic goal of a safe, useful, fun or at least livable space. In the context of socio-cultural functions, housing is seen as an area for recreation and identification and can be regarded as a psychological identity, the basis for security and self-respect (Aroni, 1982) support the community (Johnson 2006), and the setting for the formation of social relationships (Amole, 1997).

\subsection{Appearance}

Appearance is generally one exterior side of a building, usually, but not always, the front. In architecture, the appearance of a building is often the most important aspect from a design standpoint, as it sets the tone for the rest of the building. From the engineering perspective of a building, the appearance is also of great importance due to its impact on energy efficiency (Boswell, 2013). The house appearance is an important architectural element that is able to express the function and meaning of a building (Krier, 1988). The appearance of house is not as to meet the "natural conditions" which are determined by the organization and the space behind it, but the important thing is the cultural circumstances when the building was constructed include the ornament and decoration, interior design.

\subsection{Consumer Preference}

Kotler (2010) defines consumer preferences as an option like or dislike the person against products (goods or services) are consumed. Consumer preference indicates consumer preferences from a wide selection of products available. Analysis of consumer preferences is an analysis that aims to find out what she likes and dislikes of consumers, as well as to determine the order of importance of the attributes of the product and the product itself. By using this preference analysis will be obtained order of importance of product characteristics such as what is the most important or most preferred (Oktaviani, 1996).

There are many axioms to explain the behavior of individuals in problem determination for a product choice. Preference relations usually assumed to have three basic properties, namely: (Nicholson, 1994) 


\section{Teknik, 36 (2), 2015, 93}

1. Completeness

Completeness implies if $\mathrm{A}$ and $\mathrm{B}$ are two conditions or situations, then each person must always be able to specify whether:
a. A is preferred over B
b. $\mathrm{B}$ is preferred over $\mathrm{A}$, or
c. A and B are equally preferred

Everyone assumed not to be confused in determining the choice of this basic reference because everyone knows what is good and what is bad, therefore, always be settled between the two alternatives.

2. Transitivity

Transitivity: if someone claimed to prefer A than $\mathrm{B}$, and more like $\mathrm{B}$ than $\mathrm{C}$, then that person should be like A than $C$. Thus, one can not articulate conflicting preferences.

3. Continuity

Continuity ie if someone claimed to prefer A than $\mathrm{B}$ means all conditions under option $\mathrm{A}$ is preferable to the conditions under option $\mathrm{B}$.

It is assumed the preferences of each person will follow the above basis. Thus, each person will always be able to create or compile rankings in all situations or conditions ranging from most preferred to least preferred from a wide variety of goods and services available.

\section{Materials and Method}

\subsection{Research Method}

This study is related to the behavior of the human relationship with the environment with the phenomenon and the data obtained in the field so that finding the conclusions and new findings. In this study is to explore the phenomenon of data exposure through logical thinking, behavior mapping and discussions on the theory of consumer preference. While the analysis of research is qualitative analysis. The qualitative analysis used to interpret the figures obtained from the data processing as well as providing an overview.

\subsection{Population and Sample}

The population is a collection of individuals or objects of research that has the qualities and characteristics that have been set and at least one characteristic equation (Cooper and Emory, 1997). The population in this study are visitors from housing exhibition held in several shopping centers, in Mall Semarang that are Paragon, Citraland Mall, Simpang Lima Plaza, ADA Department Store. The process of questionnaires distribution is the writer distributed questionnaires in the 4 Mall in Semarang in 10 days and the respondents will fill out the questionnaires. The details in responds of questionnaires will be appear in chapter 4 questionnaires distributions.

The sampling technique used is random sampling. Sample in this study was the visitors who are serious about doing transactions with the developer. It is hard to get the visitor who is doing transaction, so the researcher collect data from the developers about the visitors who had transaction and from these data, reseacher can start to interview or giving the questionairres.

\subsection{Data Collection Techniques and Analysis}

Data collection techniques is by distributing the questionnaires and observation. The analytical method used is respondent perception about consumer preference in type of house appearance with descriptive analysis. This method analysis that is make the table in comparison for each respondents answer which type of housing they want and the reason why and make rating from the respondents preference of housing.

\section{Results and Discussion}

In this section is the result and analysis that is to analyze the consumer preference in type of house appearance, use the questionnairres among 50 samples. The following are the respondents respond about the type of housing: the type I (minimalist) is the most prefer by the consumers with response rate 19 people (38\%) (Figure 1), the second prefer is the type III (Vernacular) with response rate 14 people $(28 \%)$ (Figure 2), the third is type II (Tropic) with response rate 9 people (18\%) (Figure 3), the last one is type IV (Classic) with the response rate only 8 people (16\%) (Figure 4).
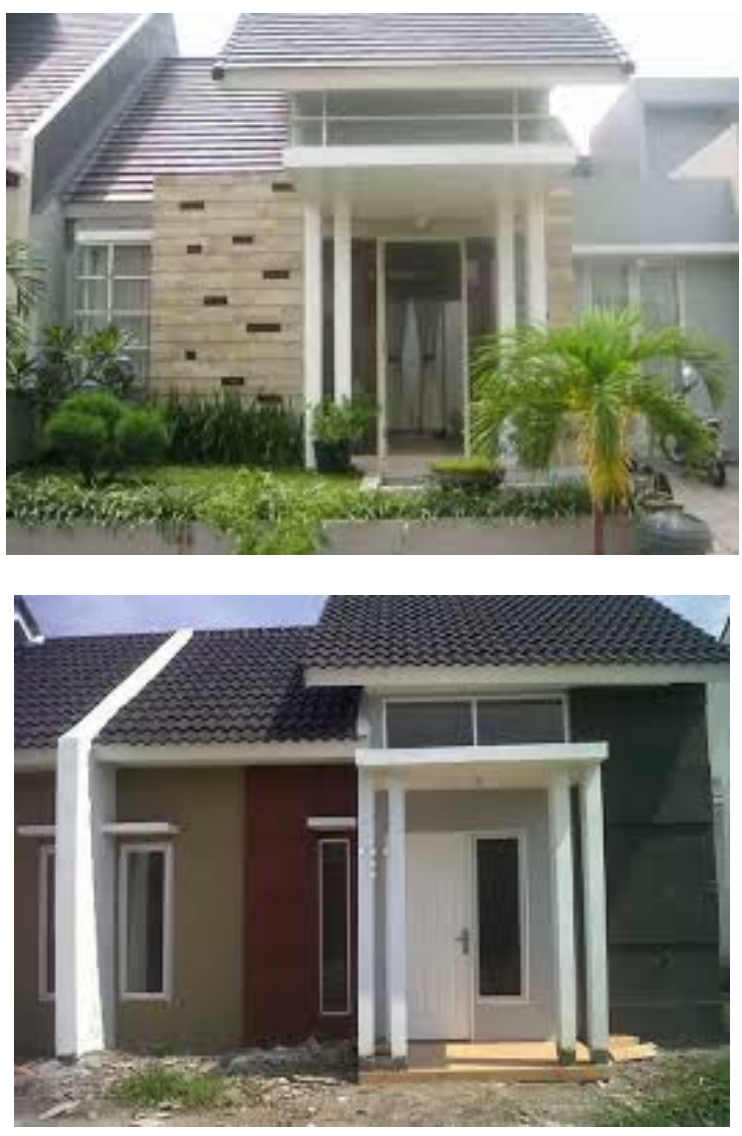

Figure 1. Type 1 Minimalist (Personal Documentation) 


\section{Teknik, 36 (2), 2015, 94}
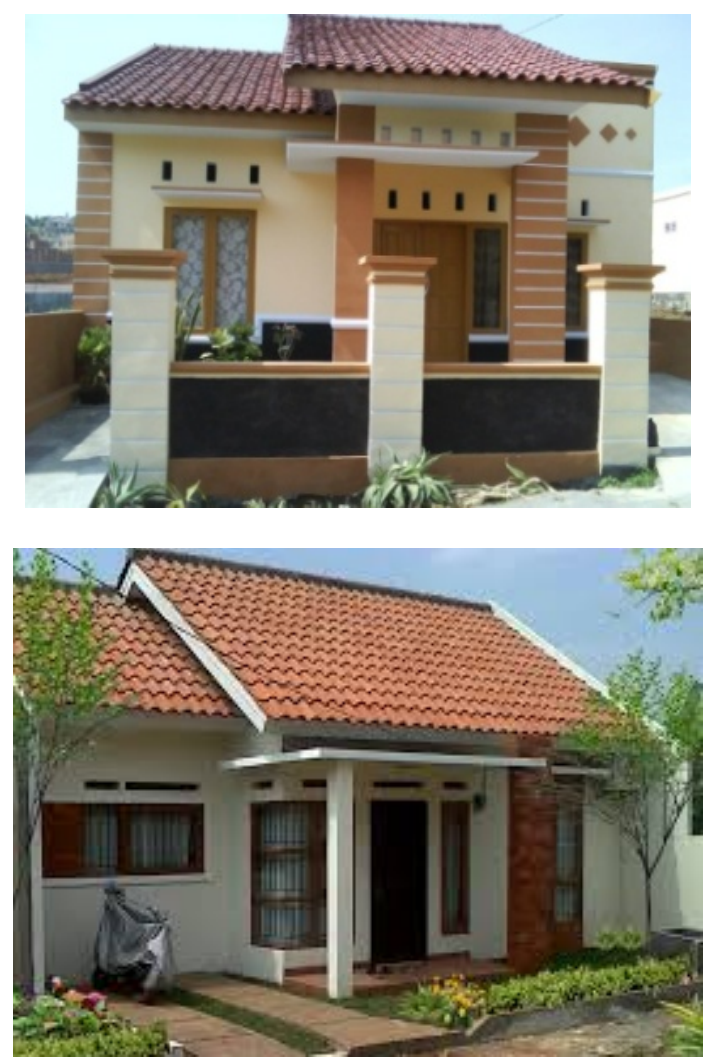

Figure 2. Type II Tropic (Personal Documentation)
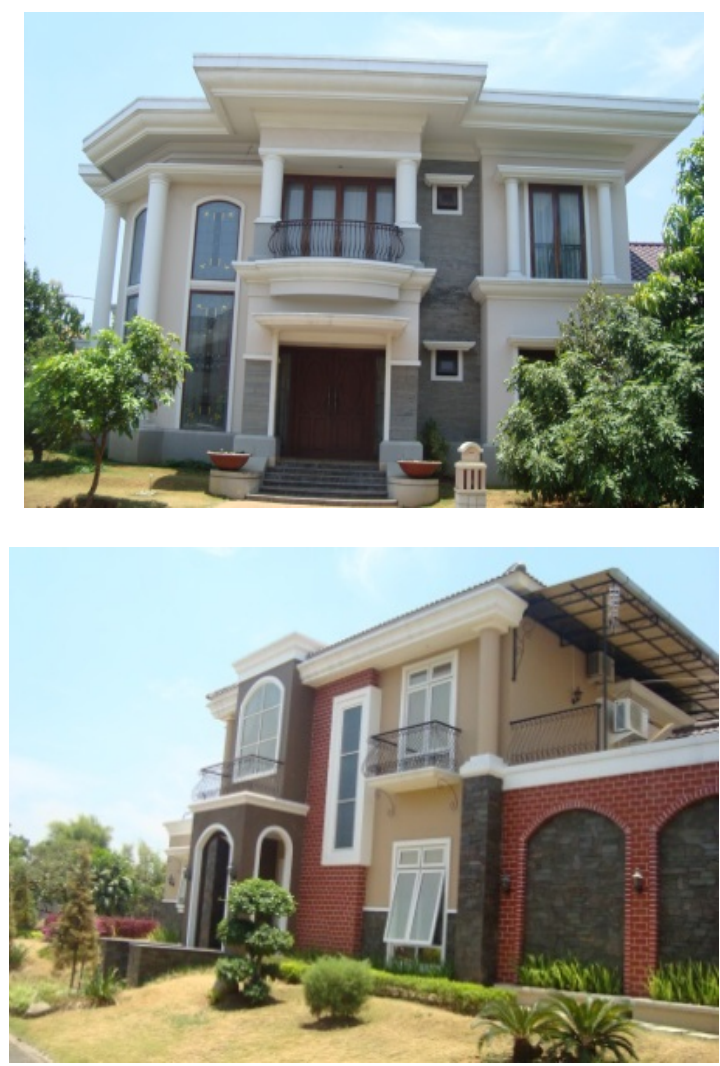

Figure 3. Type III Vernacular (Personal Documentation)
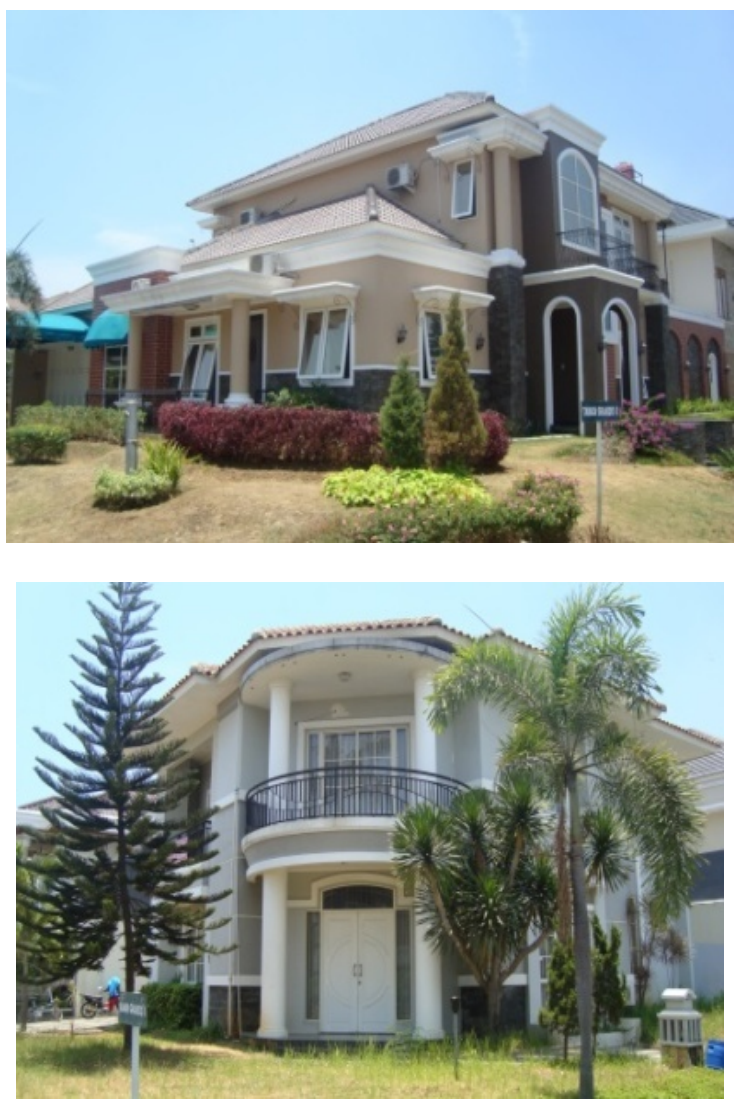

Figure 4. Type IV Classic (Personal Documentation)

Respondents said that they prefer to minimalist because the spare and streamlined is charming in almost any space. Type Minimalist also have uniqness that is very simple and attractive also modern. With less clutter to wade through and mentally process, the innate beauty of each piece of furniture or art in the home really starts to stand out. Minimalist type is very popular. Meanwhile the second is Vernacular, whereas this type is the most likely type for the highest class social because this type very big and reflect the cultures design. The vernacular architecture is not to be confused with so-called "traditional" architecture, though there are links between the two. Traditional architecture also includes buildings, which bear elements of polite design: temples and palaces, for example, which normally would not be included under the rubric of "vernacular." In architectural terms, 'the vernacular' can be contrasted with 'the polite', which is characterised by stylistic elements of design intentionally incorporated by a professional architect for aesthetic purposes which go beyond a building's functional requirements. Between the extremes of the wholly vernacular and the completely polite, examples occur which have some vernacular and some polite content, often making the differences between the vernacular and the polite a matter of degree. 


\section{Teknik, 36 (2), 2015, 95}

Table 1. Occupation and Type House Preference

\begin{tabular}{cccccccc}
\hline & \multicolumn{7}{c}{ Occupation } \\
\cline { 2 - 6 } Type & $\begin{array}{l}\text { Freel } \\
\text { ance }\end{array}$ & $\begin{array}{l}\text { Ente } \\
\text { rpre } \\
\text { neur }\end{array}$ & $\begin{array}{l}\text { Art } \\
\text { ist/ } \\
\text { Mo } \\
\text { del }\end{array}$ & $\begin{array}{l}\text { Con } \\
\text { sulta } \\
\text { nt }\end{array}$ & $\begin{array}{l}\text { Em } \\
\text { plo } \\
\text { yee }\end{array}$ & $\begin{array}{l}\text { Gover } \\
\text { ment } \\
\text { emplo } \\
\text { yee }\end{array}$ & Total \\
\hline I & 2 & 6 & 0 & 1 & 9 & 1 & 19 \\
II & 1 & 4 & 1 & 1 & 2 & 0 & 9 \\
III & 0 & 11 & 1 & 1 & 1 & 0 & 14 \\
IV & 0 & 3 & 0 & 0 & 2 & 3 & 8 \\
\hline Total & 3 & 24 & 2 & 3 & 14 & 4 & 50 \\
\hline
\end{tabular}

From Table 1, the result of crosstabulation between respondents occupation and type house majority responden choose type III (Vernacular) is enterpreneur (11 persons) and majority respondents choose type I (Minimalist) is employee. This condition happens because they that have occupancy as employee also we know as the middle low class, like the minimalist type of house because the price lower and also it is simple. Meanwhile, the entrepreneur who is the high class prefer the vernacular type of house because it is elegant and luxury, also the price higher.

Result of consumer response about the type of house influence the consumer in determining the purchase of a house because majority of respondents Agree with average score is 3,40 . The highest score is type minimalist $(3,76)$ and the second is vernacular $(3,62)$. The third rank is type tropic $(3,12)$ and the last is classic type $(3,00)$. This indicate that the consumer preference in type minimalist is the most interested because this type especially for the middle social class with the average price.

The appearance of a home is important to attract buyers. The better the quality and the shape of the house then the consumer will be more interested in buying the output offered by the company property. From the result testing we can say that there is some factors affecting consumers perception in buying a house, such as type house, space, location, facility, price, advertising, bonus.

\section{Conclusion}

The house type consumer prefer most is type minimalist (middle lower classs) and the second is Vernacular type (high social slass). This is because the spare and streamlined is charming in almost any space. Type Minimalist also have uniqness that is very simple and attractive also modern. Minimalist type is very popular and the price lower. Meanwhile, the type vernacular prefer almost by the enterpreneur that come from the high class society and they say type vernacular is big and luxury, also georgeous.

\section{References}

Abrams, C. (1964). Housing in the Modern World. Man'es Struggle for Shelter in an Urbanizing World. Africa Today, 11(8). 12-14: Indiana University Press.

Ahsen, O. \& Gulcin, P.G. (2005). Space use, dwelling layout and housing quality: an example of low cost housing in Istanbul. England: Ashgate publishing Limited.

Amole, O.O. (1997). An Evaluation of Students ${ }^{\text {ee }}$ Residential Facilities in Some Nigerian universities. Ph.D Thesis, submitted to the Department of Architecture Obafemi Awolowo University, Ile-Ife.

Aroni, S. \& Hasson, S. (1982). The Meaning of Public Housing in Los Angeles: Contradictory Functions and Values. ITCC Review. (44) 2131.

Boswell, Keith. (2013) Exterior Building Enclosures. John Wiley \& sons, Inc, p. 11.

Johnson, M. P. (2006). Decision Models for Affordable Housing and Sustainable Community Development. Carnegie Mellon University, 5000 Forbes Ave. Pittsburgh, PA 15213-3890, Submission to special issue of Journal of the American Planning Association.

Kotler, P. (2010). Marketing Management. Prentice Hall.

Krier, L. (1988). Architectural Design. Domus, 58 (1), May 1988.

Nicholson, M. (1994). Formal methods of analysis in IR: A Guide to Theory. New York: Pint Publishers.

Ogunsakin, L. (1988). Urbanisation and Urban Housing in the Third World. Unpublished Ph.D Thesis, Submitted to Aristotle University of Thessalonika; Greece.

Oktaviani. (1996). Consumer Preference. Jakarta: Erlangga.

Salau. (1992). Consumer Behavior. 8th edition, Prentice Hall. 